\title{
SVE Miniature Slide Projector
}

\author{
By Yvonne M. Johnson
}

\section{How did the slide projector impact education?}

Slide projectors provided schools the opportunity to benefit from innovations in photography and reductions in equipment costs. These advances allowed schools to purchase new visual instruction equipment and to use still images as instructional tools (O'Toole, 2003).

Records indicate that the slide projector was marketed in the 1930's for classroom use (Dent, 1969). Dent (1939) noted that slide projectors were also used in churches, industry and government. The small slide projector was easier to store and operate then prior models, such as lantern projectors. Additionally, the lower cost of the slide projector was a welcome option during the challenging economic years of the Depression.

Educators welcomed the freedom provided by the slide projector (O'Toole, 2003). Teachers were able to design unique, visual presentations that could be shown in the order selected by the presenter, and the value of using still pictures rather than motion pictures to portray landmarks, such as Stone Mountain, and other inanimate objects was recognized (Dent, 1939).

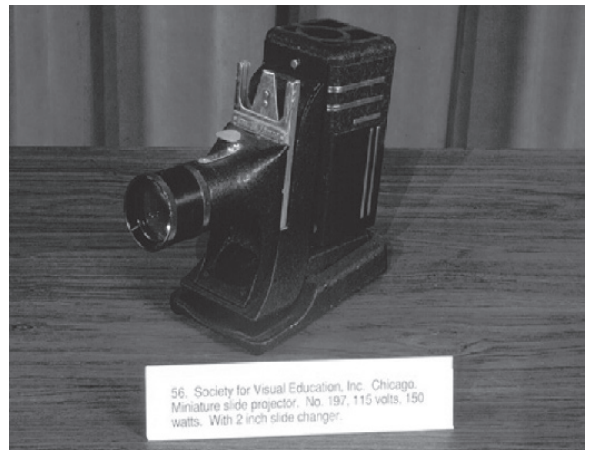

Lee and Lida Cochran AECT Archives Blackwell Museum of Education Northern Illinois University 1999

\section{References}

Dent, D. (1939). The audio-visual handbook. Chicago: Society for Visual Education.

Dent, D. (1969). Landmarks in learning: The story of SVE. Chicago: Society of Visual Education.

Lee and Lida Cochran AECT Archives. (1999), DeKalb, Illinois: Blackwell Museum of Education, Northern Illinois University. Retrieved from http://www.cedu.niu.edu/ blackwell/multimedia/high/library.html

O'Toole, K. (2003). The Story of the SVE DK Miniature Projector. AECT Archives Paper. DeKalb, Illinois: ETT 640, Northern Illinois University. 